\title{
First Ediacaran Fauna Occurrence in Northeastern Brazil (Jaibaras Basin, ?Ediacaran-Cambrian): Preliminary Results and Regional Correlation
}

\author{
FRANCISCO R.G. BARROSO ${ }^{1}$, MARIA SOMÁLIA S. VIANA ${ }^{2}$, \\ MARIO F. DE LIMA FILHO ${ }^{1}$ and SONIA M.O. AGOSTINHO ${ }^{1}$ \\ ${ }^{1}$ Universidade Federal de Pernambuco/UFPE, Laboratório de Geologia Sedimentar e Ambiental/LAGESE, \\ Av. Acadêmico Hélio Ramos, s/n, Cidade Universitária, 59740-530 Recife, PE, Brasil \\ ${ }^{2}$ Universidade Estadual Vale do Acaraú, Museu Dom José, Laboratório de Paleontologia, \\ Av. Dom José Tumpinambá, 878, Centro, 62010-290 Sobral, CE, Brasil \\ Manuscript received on May 24, 2013; accepted for publication on September 9, 2013
}

\begin{abstract}
This study reports the first known occurrence of the Ediacaran fauna in northeastern Brazil (at Pacujá Municipality, northwestern state of Ceará) and presents preliminary interpretations of its significance. Regional correlation indicates that the fossils originated in the Jaibaras Basin and that they may represent a new geological system. The depositional environment can be attributed to a fluviomarine system. Nine Ediacaran species can be identified, including members of pandemic groups (e.g., Charniodiscus arboreus Glaessner, 1959; ?Charniodiscus concentricus Ford, 1958; Cyclomedusa davidi Sprigg, 1947; Ediacaria flindersi Sprigg, 1947; and Medusinites asteroides Sprigg, 1949) and endemic groups (e.g., Kimberella quadrata Glaessner \& Wade, 1966; Palaeophragmodictya reticulata Gehling \& Rigby, 1996; Parvancorina minchami Glaessner, 1958; and Pectinifrons abyssalis Bamforth, Narbonne, Anderson, 2008). Three ichnogenera are also present: Arenicolites Salter, 1857; Palaeophycus Hall, 1987; and Planolites Nicholson, 1873. The relative age of the deposits is between ?Ediacaran and Cambrian, and the fauna resembles the White Sea Assemblage. The bioturbation presents typical unbranched Ediacaran ichnogenera with little depth in the substrate. This previously unknown occurrence of the Ediacaran fauna reinforces the importance of the state of Ceará to Brazilian and global palaeontology.
\end{abstract}

Key words: Brazil, state of Ceará, Ediacaran fauna, fluviomarine environment, White Sea Assemblage.

\section{INTRODUCTION}

This preliminary study reports the first known occurrence of the Ediacaran fauna in northeastern Brazil. Through regional correlation, this assemblage is attributed to the Jaibaras Basin. The study area is located east of the city of Pacujá in

Correspondence to: Francisco Rony Gomes Barroso

E-mail: ronybarroso@hotmail.com northwestern state of Ceará (Figure 1), on outcrops distributed along the banks of Lameirão Creek and within the Contra Fogo Farm.

The Ediacaran fauna comprises the most primitive metazoa known to have existed on Earth. These organisms, which lived between 565 and $541 \mathrm{Ma}$, lacked mineralised skeletons. The name is taken from the famous Ediacara Hills in Australia 


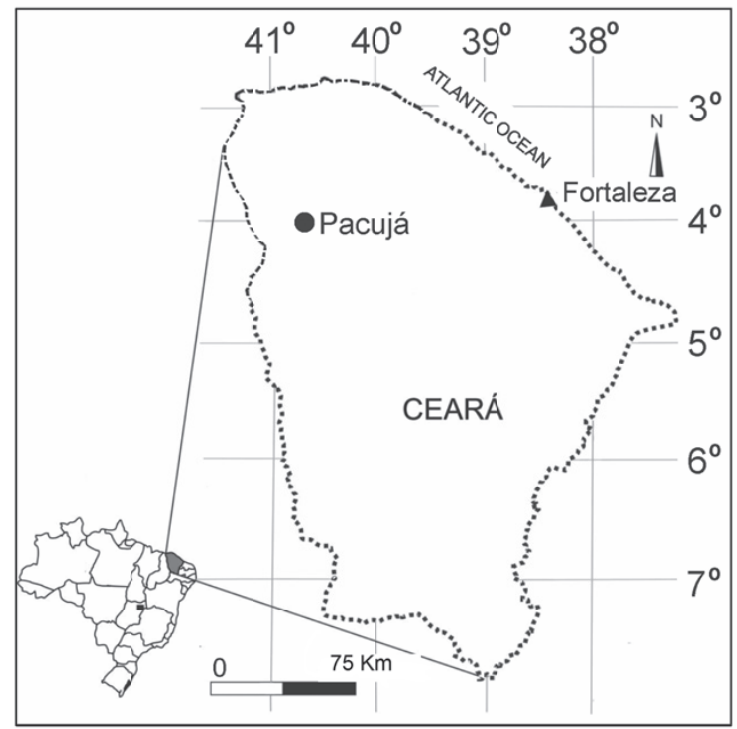

Figure 1 - Geographical location of the study area.

(Waggoner 1998, 2003). The occurrence of Ediacaran organisms is commonly associated with ichnofossils, marks thought to have been made by different animals (Fairchild and Boggiani 2010, Netto 2012, Seilacher 1992).

Current evidence suggests that the evolution of the Ediacaran fauna was triggered by major global physical and chemical changes during the Neoproterozoic, starting with the rupture and dispersion of the supercontinent Rodinia and the subsequent agglomeration of a group of descendent fragments to form a new supercontinent called Gondwana (Narbonne 2005).

In Brazil, the final Gondwanan configuration is represented by the Brasiliano Cycle (Brito Neves et al. 2001), which is recorded in northwestern Ceará by the formation of the Jaibaras Graben (Figure 2) with the development of a volcanic-sedimentary sequence known as the Jaibaras Basin (Oliveira and Mohriak 2003).

Sedimentation resumed at the end of the Brasiliano Cycle, during the stabilisation stage of the South American Platform (Silurian Period). This sedimentary phase is represented by the Serra Grande Group of the Parnaíba Basin (Mabessone 2002),
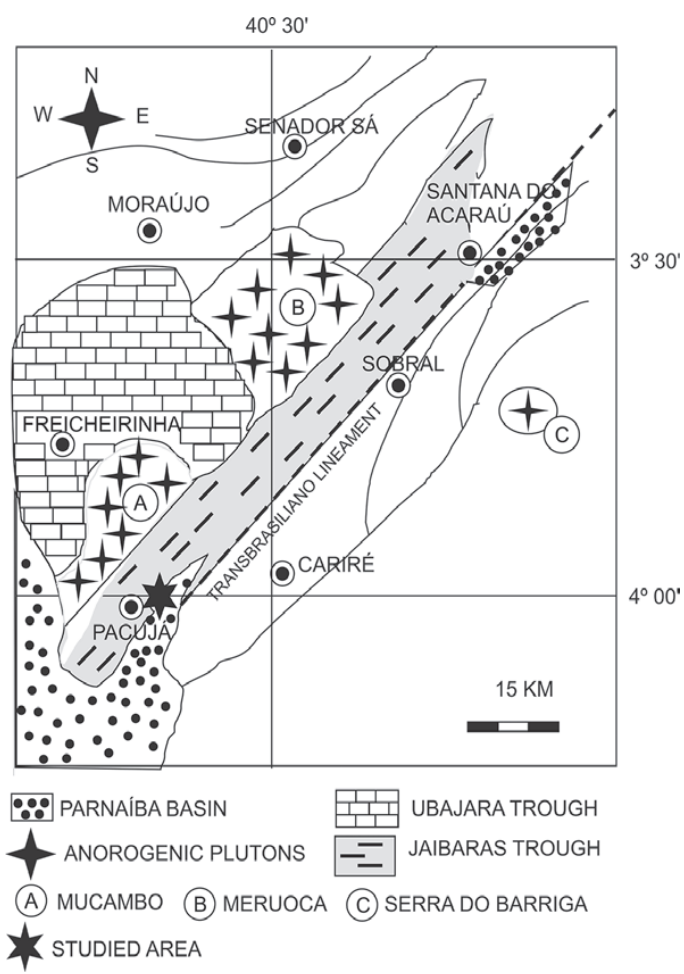

Figure 2 - Regional geology of northeastern Ceará (Modified from Oliveira and Mohriak 2003).

which extends over the sediments of the Jaibaras Basin (Vaz et al. 2007).

Although the first occurrence of the Ediacaran fauna in northeastern Brazil is geographically located in the Parnaíba Basin, the fossil-bearing deposits are herein considered to belong to the Jaibaras Graben because the molasse basins or volcanic-sedimentary sequences are closely related to the emergence and preservation of the Ediacaran fauna in the global Neoproterozoic-Cambrian context.

RESEARCH HISTORY

Previously, the only known occurrences of Ediacaran fossils in Brazil were those found in the Corumbá Group in the state of Mato Grosso do Sul [carbonate deposits containing Cloudina Germs, 1972 and Corumbella Hahn, 1982 (Babcock et al. 2005)] and in the Camarinha Formation in the state of Paraná [containing Beltanelliformis Menner, 1974 (Drefahl and Silva 2007)]. Netto (2012) 
reported occurrences of icnhofauna associated to the Ediacaran biota in the states of: Santa Catarina (Itajaí Basin), Paraná (Camarinha Basin) and Rio Grande do Sul (Camaquã Basin). The ichnofossils found in the Southern region were: Beltanelliformis Menner, 1974; Bergaueria hemisphaerica Crimes, Legg, Marcos \& Arboleya, 1997; Cochlichnus Hitchcock, 1858; Palaeophycus Hall, 1987; and Planolites Nicholson, 1873. The associated Ediacaran biota were: Aspidella Billings, 1872; Intrites Fendonkin, 1980; and Sekwia Hofmann, 1981.

Numerous publications have addressed the regional geology of northwestern Ceará, including the Jaibaras Basin (Costa et al. 1973, Kegel et al. 1958, Oliveira 2001, Oliveira and Mohriak 2003, Santos and Brito Neves 1984, Schobbenhaus and Brito Neves 2003, Torquato 1995, Torquato and Nogueira Neto 1996).

To date, however, little palaeontological information has been available for the study area, and no Ediacaran fossils have been recorded in northeastern Brazil.

\section{GEOLOGICAL FrAMEWORK}

Northwestern state of Ceará is located within the Borborema Province (the northeastern portion of the South American Platform). Thermal, tectonic, magmatic and other geological activities occurred in this area during the Late Proterozoic, lasting through the Cambrian-Ordovician (F.F.M. Almeida et al., unpublished data). This region, known as the Médio Coreaú Domain, was a source area of substantial rupture mobility throughout the late Precambrian, resulting in a general trend of subsidence processes (Santos and Brito Neves 1984). The structure of the area comprises horsts and grabens separated by ancient deep shear zones (Oliveira 2001).

This study focused on the Jaibaras Basin (Figure 2), which forms part of the Médio Coreaú System. The Jaibaras Basin is bounded by the Palaeozoic Parnaíba Basin to the west, the Transbrasiliano Lineament to the south and east and the Ubajara
Basin to the north. It is filled by immature siliciclastic sediments, and its full sedimentary sequence (formally known as the Jaibaras Group) comprises, from bottom to top, the Massapê, Pacujá and Aprazível Formations (Oliveira 2000).

The Ubajara Graben (Neoproterozoic) represents the basal sequence of the Jaibaras Basin. Its rocks underwent continuous low-grade metamorphism during the Brasiliano Cycle, generating strongly penetrative mineral foliation (Oliveira and Mohriak 2003). This Graben was filled under fluviomarine conditions, and an important carbonate facies (the Frecheirinha Formation) is present in the intermediate portion of the sequence (Delgado et al. 2003).

The Jaibaras Graben was filled by cogenetic processes resulting from sedimentary input and magmatic events (Oliveira 2000), mainly during the Ediacaran period (Table I). The Coreaú Dyke Swarm, of Vendian age, represents the initial stage of rift opening. Prior to the filling of the graben, the evolution of this distension system during the Lower Cambrian permitted the accommodation of the Mucambo Pluton. During the Middle Cambrian, basin sedimentation was accompanied by a considerable volume of magma (the Parapuí Suite). Subsequently, the Meruoca Pluton was formed by passive intrusion (Oliveira 2001).

In addition to the data shown in Table I, De Araújo et al. (2012) dated Neoproterozoic zircons in the Pacujá sandstone, indicating that the two main groups extended from 550 to $598 \mathrm{Ma}$ and from 600 to $630 \mathrm{Ma}$.

The sedimentary environment of the Jaibaras Group begins with a systematic repetition of conglomeratic fans, reflecting the cyclical nature of continuous basin subsidence. This phase is represented by the Massapê Formation. With continued basin subsidence, the material supply was lower than the subsidence rate, permitting the development of lakes and rivers with deltaic systems. This phase is represented by the Pacujá Formation. Terminating the sedimentary deposits 
TABLE I

Geochronological data for the major sedimentary and magmatic events of the Jaibaras Basin, indicating the minimum and the maximum value of each age.

\begin{tabular}{c|c|c|c}
\hline Event & Method & Age (Ma) & References \\
\hline \multirow{2}{*}{ Coreaú Dykes } & $\begin{array}{c}\mathrm{Rb} / \mathrm{Sr} \text { (isochronous) } \\
\mathrm{Rb} / \mathrm{Sr} \text { (isochronous) }\end{array}$ & $\begin{array}{c}605 \pm 31 \\
562 \pm 10\end{array}$ & $\begin{array}{c}\text { B.B Brito Neves et al. (unpublished data) } \\
\text { Tavares Jr et al. (1990) }\end{array}$ \\
\hline \multirow{2}{*}{ Mucambo Pluton } & $\begin{array}{c}\mathrm{Rb} / \mathrm{Sr} \text { (isochronous) } \\
\mathrm{K} / \mathrm{Sr} \text { (total rock) }\end{array}$ & $548 \pm 24$ & $\begin{array}{c}\text { Sial et al. (1981) } \\
\text { Vandoros and Oliveira (1968) }\end{array}$ \\
\hline \multirow{2}{*}{ Pacujá Formation } & $\begin{array}{c}\mathrm{Rb} / \mathrm{Sr} \text { (isochronous) } \\
\text { metamorphism }\end{array}$ & $535 \pm 27$ & F.R.G. Novais et al. (unpublished data) \\
\hline \multirow{2}{*}{ Parapuí Suite } & $\begin{array}{c}\mathrm{K} / \mathrm{Ar} \text { (total rock) } \\
\mathrm{K} / \mathrm{Ar} \text { (total rock) }\end{array}$ & $502 \pm 8$ & F.R.G. Novais et al. (unpublished data) \\
& $\mathrm{Rb} / \mathrm{Sr}$ (isochronous) & $540 \pm 7$ & P. Vandoros (unpublished data) \\
\hline \multirow{2}{*}{ Meruoca Pluton } & $\mathrm{K} / \mathrm{Ar}$ (K-feldspar) & $446 \pm 15$ & Novais apud Oliveira (2001) \\
\end{tabular}

in the basin, large alluvial fans brought an input of paraconglomerates with fragments that were compositionally similar to the underlying formations as well as fragments from the plutons and from the Parapuí Suite, whose assembly is recorded by the Aprazível Formation (Oliveira and Mohriak 2003).

With the attenuation of the Brasiliano tectonic cycle, the Borborema Province underwent a transition phase with post-orogenetic conditions. At the end of this phase, Saharan glaciations were manifested in the region by the Serra Grande Group, which is located in proximity to the area in Africa where this glaciation was (Mabessone 2002).

\section{RESULTS}

FIELDWORK

The research area exhibits the typical lithological characteristics of the Pacujá Formation, including fine/silty, reddish, micaceous sandstone, planeparallel lamination and ripples. The formation is underlain by unconforming volcanoclastic breccias containing fragments of sandstones and basic volcanic rocks surrounded by a strongly recrystallised silt matrix and overlain by fine sandstone with plane-parallel lamination.
The fossiliferous deposits differ from the Pacujá Formation, presenting coarse, fossiliferous, strongly silicified and immature sandstone with cream, yellowish, beige and sometimes grey colours. These deposits exhibit, at the base, horizontal lamination with planar cross bedding and low diversity of Ediacaran fauna, followed to the top, trough crossbedding and symmetrical ripple marks with higher diversity that helped characterise a meandering fluvial system near a river mouth. This sandstone, herein informally called the Contra Fogo Sandstone, occurs as a thick lobe oriented from south to north in the Jaibaras Graben and unconformingly rests on the breccias of the Pacujá Formation.

The Contra Fogo Sandstone is partially eroded and is approximately $100 \mathrm{~m}$ thick, with lateral variations. The Serra Grande Group laterally underlies it to the east (Figure 3). On current maps, the sandstones containing Ediacaran fossils are included within the Parnaíba Basin (Cavalcante et al. 2003), suggesting the need for a stratigraphic revision of the area based on these newly discovered fossiliferous deposits.

At the Contra Fogo Farm, the deposits containing the Ediacaran fauna are found within 
a $4,800-\mathrm{m}^{2}$ rectangular area. The fossils, which occur on eroded surfaces, are mostly basal discs and fronds but also include ichnofossils and associated Ediacaran bilaterians. The local preserved species diversity is approximately 5 species $/ \mathrm{m}^{2}$, with an abundance of approximately 8 individuals $/ \mathrm{m}^{2}$.
Along Lameirão Creek, where the action of fluvial waters has accelerated the erosion process and exposure of the Contra Fogo Sandstone, the fossils extend over a distance of approximately 4 $\mathrm{km}$. The diversity found at this locality is lower than that found at Contra Fogo Farm due to the absence of Ediacaran bilaterians.

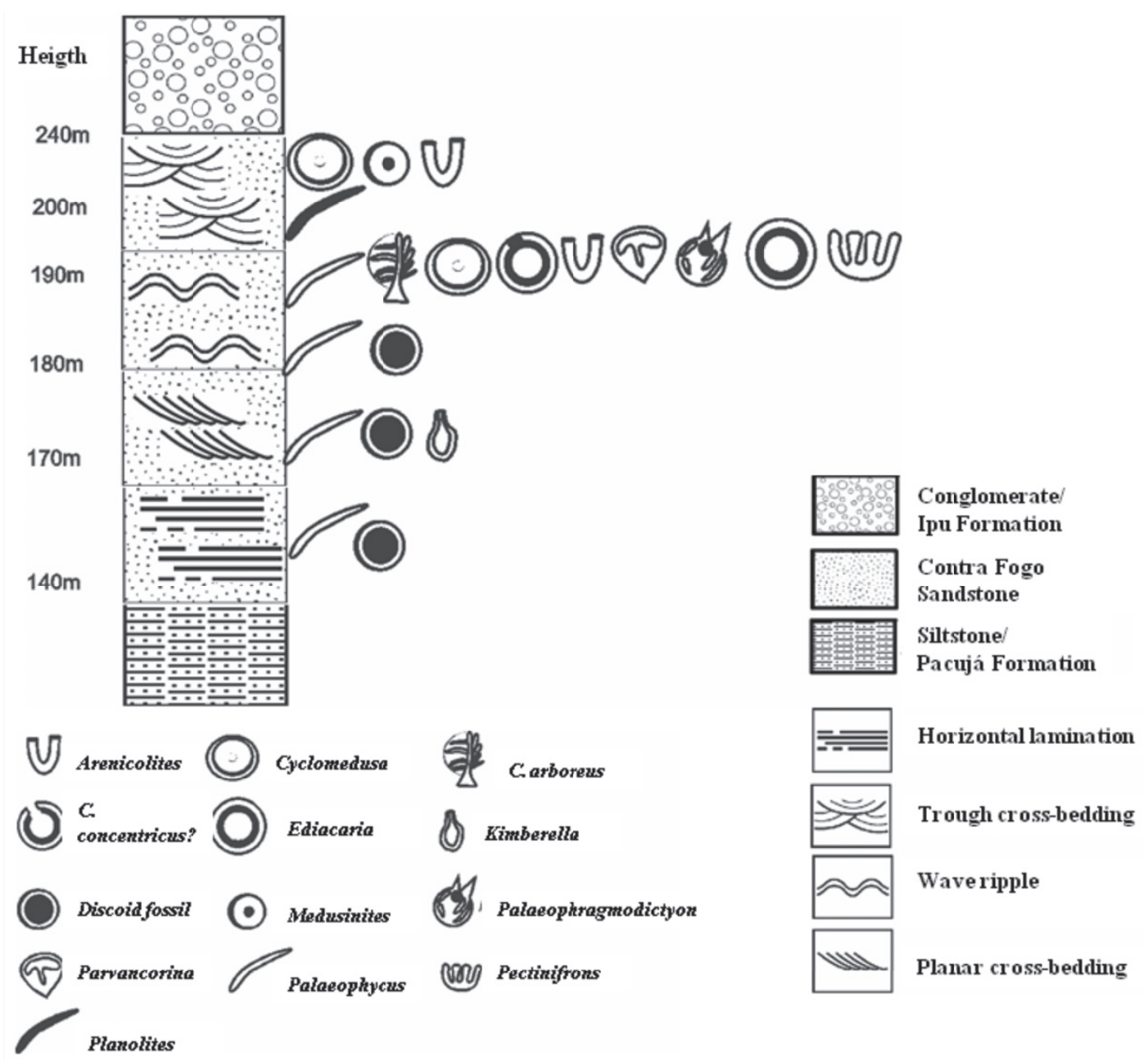

Figure 3 - Stratigraphic distribution of fossils in the profile.

\section{THE EDIACARAN FAUNA OF JAIBARAS BASIN}

Some of the Ediacaran fossils described below are stored in the Dom José Museum (MDJ) collection, located in the city of Sobral, and managed by the Laboratório de Paleontologia (LABOPALEO) of the Universidade Estadual Vale do Acaraú-UVA. The collection of Ediacaran fauna is composed by 80 specimens (MDJ Ed-01 to MDJ Ed-80), being represented mainly by discs forms. However, most of the fossils were described in the field due to the impossibility of collection. Including impressions and ichnofossils, the total number of species is estimated to exceed 30 , but only 12 have been identified to date. However, the total number of specimens exceeds thousands in all outcrops visited. 
Genus Charniodiscus Ford, 1958

Charniodiscus arboreus Glaessner, 1959

(Figure 4A)

Description: A frond-shaped impression preserved in epirelief, the petaloid sometimes in negative and sometimes in positive epirelief. Branches approximately uniform, parallel, with the primary branches diverging from the central shaft at slightly oblique angles and the distal extremities connected to an exterior edge, preserved on only one side. Central shaft $33 \mathrm{~cm}$ long and $2.5 \mathrm{~cm}$ wide at the base. Largest primary branch $9.0 \mathrm{~cm}$ long. Additional preserved discs lacking fronds may represent this species.

Material: A single specimen described and recorded in the field at the Contra Fogo Farm.

Observation: The specimen was probably not buried alive because the detachment of some primary branches from the central shaft indicates a state of decomposition. Moreover, a new disc is present at the base of the central shaft, indicating that the substrate was quickly recolonised after burial.

Discussion: The main criterion used to identify this specimen as $C$. arboreus is the oval shape of the extremity (Laflame and Narbonne 2008a). According to Laflame and Narbonne (2008b), the appearance of the branches may vary markedly in response to their preservation quality. Charniodiscus sp. shafts are usually over $30 \mathrm{~cm}$ long. Charniodiscus has been interpreted by Seilacher (1992) as Vendobionta, by Narbonne (2005) as a cnidarian and by Peterson et al. (2003) as a fungus. The latter authors stated that the shafts of the Charniodiscus specimens had apparently been filled with sand in their internal spaces, indicating that they were hollow in life and that a large channel extended over the entire length of the shaft. Charniodiscus is a pandemic genus, found at most Ediacaran localities. It is also the first Ediacaran group to appear in the fossil record, with some representatives extending into the Cambrian (Waggoner 2003).
Genus Charniodiscus Ford, 1958

Species ? Charniodiscus concentricus Ford, 1958 (Figure 4B)

Description: Only the basal disc of this species was observed. The disc is a bipartite circular impression in positive epirelief, $6.9 \mathrm{~cm}$ in width and $13 \mathrm{~cm}$ in total diameter. Outer edge $3.3 \mathrm{~cm}$ wide, separated from the inner disc by a depression. Inner disc $6.0 \mathrm{~cm}$ in diameter. Edge of the outer disc perpendicularly cut by a long, narrow depression.

Material: MDJ Ed-007, found at the Contra Fogo Farm.

Observation: The depression perpendicular to the outer disc represents the contact of the shaft on the disc during the fall of the frond onto the substrate. The exclusive preservation of the disc was probably facilitated due to it being already buried in the sediment.

Discussion: This species was initially described by Ford (1958 apud Ford 1999) from a volcanic-sedimentary sequence in Charnwood Forest, Leicestershire, England. Subsequently, Martin Glaessner found similar individuals in the Ediacara Member in Australia (McCall 2006). A fully preserved frond species, $25 \mathrm{~cm}$ in length, found in Charnwood Forest (Ford 1999) facilitated the identification of the Charniodiscus concentricus specimen from Pacujá. Notably, this specimen appears to be associated with Cyclomedusa and some typically Vendian discrete ichnofossils.

Genus Cyclomedusa Sprigg, 1947

Species Cyclomedusa davidi Sprigg, 1947

(Figure 4C)

Description: A bipartite circular impression in positive epirelief, $12 \mathrm{~cm}$ in diameter. Inner disc surrounded by an outer disc with a slightly raised edge, $1.5 \mathrm{~cm}$ in width. Inner edge raised above the outer edge, $7.0 \mathrm{~cm}$ in diameter, with a central depression $1.5 \mathrm{~cm}$ in diameter. 
Material: Described and photographed in the field at the Contra Fogo Farm.

Discussion: The central depression has been interpreted as a Cyclomedusa subtype Ford (1999), and it has frequently been called Cyclomedusa cliffi. These impressions are by far the most common type in Charnwood Forest, with diameters varying from less than $1 \mathrm{~cm}$ to $22 \mathrm{~cm}$. The Charnwood Forest specimens lack striations, but the Australian Cyclomedusa species do present these structures (Ford 1999). Jenkins (1992, p. 157, apud Crimes and McIlroy 1999) considered C. plana, C. radiata, Springginia annulata Sprigg, 1949, Medusinites asteroides Sprigg, 1949 and possibly Ediacaria flindersi Sprigg, 1947 to be synonymous because of their recorded associations. The phylogenetic placement of Cyclomedusa sp. has been attributed to cnidarians (McCall 2006).

Genus Ediacaria Sprigg, 1947 Species Ediacaria flindersi Sprigg, 1947

(Figure 4D)

Description: A bipartite circular impression in positive epirelief (though fragmented), $17 \mathrm{~cm}$ in total estimated diameter. Central disc $10 \mathrm{~cm}$ in diameter, surrounded by an outer disc $4.5 \mathrm{~cm}$ in width. Inner disc slightly raised above the outer disc, representing $3 / 4$ of the impression size. Radial grooves absent.

Material: MDJ Ed-53, found at the Contra Fogo Farm.

Discussion: Ediacaria flindersi is the largest and most common medusoid known from the various Ediacaran assemblages (De 2006). Glaessner and Wade (1966) stated that radial structures may or may not appear in the specimens and that the largest complete specimen from Australia was 12 $\mathrm{cm}$ in diameter. However, other fragments have indicated specimens much larger than $21 \mathrm{~cm}$. The phylogenetic affinity of Ediacaria has also been attributed to cnidarians (McCall 2006).
Genus Kimberella Glaessner and Wade, 1966 Species Kimberella quadrata Glaessner and Wade, 1966 (Figure 4E)

Description: An oval-shaped impression with the distal portions showing a relatively inflated outer edge and a distorted, raised internal zone. Anterior extremity with a neck-shaped structure. Transverse U-shaped partitions not present on the inflated edges, possibly due to the sediment particle size. Anteroposterior length $5 \mathrm{~cm}$, edge width $1 \mathrm{~cm}$, width of the inner depression $0.5 \mathrm{~cm}$.

Material: One specimen recorded and photographed in the field at the Lameirão creek.

Discussion: Kimberella quadrata from northeastern Brazil resembles the "C" subtype of Ivantsov (2009). Notably, the latter group of specimens is endemic to Russia and Australia, where it is included in the White Sea Assemblage and found in association with medusoid fossils and ichnofossils. Fedonkin and Waggoner (1997) reconstructed Kimberella quadrata as a symmetrical bilaterian, a benthic animal with a univalvate and nonmineralised shell, similar to a mollusc. This specimen described here is of average length and size.

Genus Medusinites Glaessner, 1966

Species Medusinites asteroides Sprigg, 1949

(Figure 4F)

Description: A bipartite circular impression in positive epirelief. Outer raised disc separated from the inner disc by a deep surrounding depression. Radial grooves preserved in the edge of the outer disc, oriented toward the central disc. Central disc relatively smaller, with a total diameter of $10 \mathrm{~cm}$.

Material: One specimen described and photographed in the field at the Lameirão creek.

Discussion: Specimens with diameters of 1 to $5 \mathrm{~cm}$ have been identified in Australia (Glaessner and Wade 1966) and Africa (Bertrand-Sarfat et al. 1995). However, the Pacujá specimen has a diameter twice as large. Medusinites spp. are considered to be sedentary medusoid cnidarians (McCall 2006). 
Class Hexactinellida Schmidt, 1870

Order Reticulosa Reid, 1958

Superfamily Dictyospongioidea Hall and Clarke, 1899

Genus Palaeophragmodictya

Species Palaeophragmodictya reticulata Gehling and Rigby, 1996

(Figure 4G)
Description: A circular mould in negative epirelief, including a depressed smaller disc. Smaller disc tending toward one of the extremities and irregularly surrounded by raised edges. Two attached structures present in negative relief, triangular in shape, with their bases externally surrounding the larger disc. Larger disc $13 \mathrm{~cm}$ in diameter, smaller depressed disc $3 \mathrm{~cm}$ in diameter.
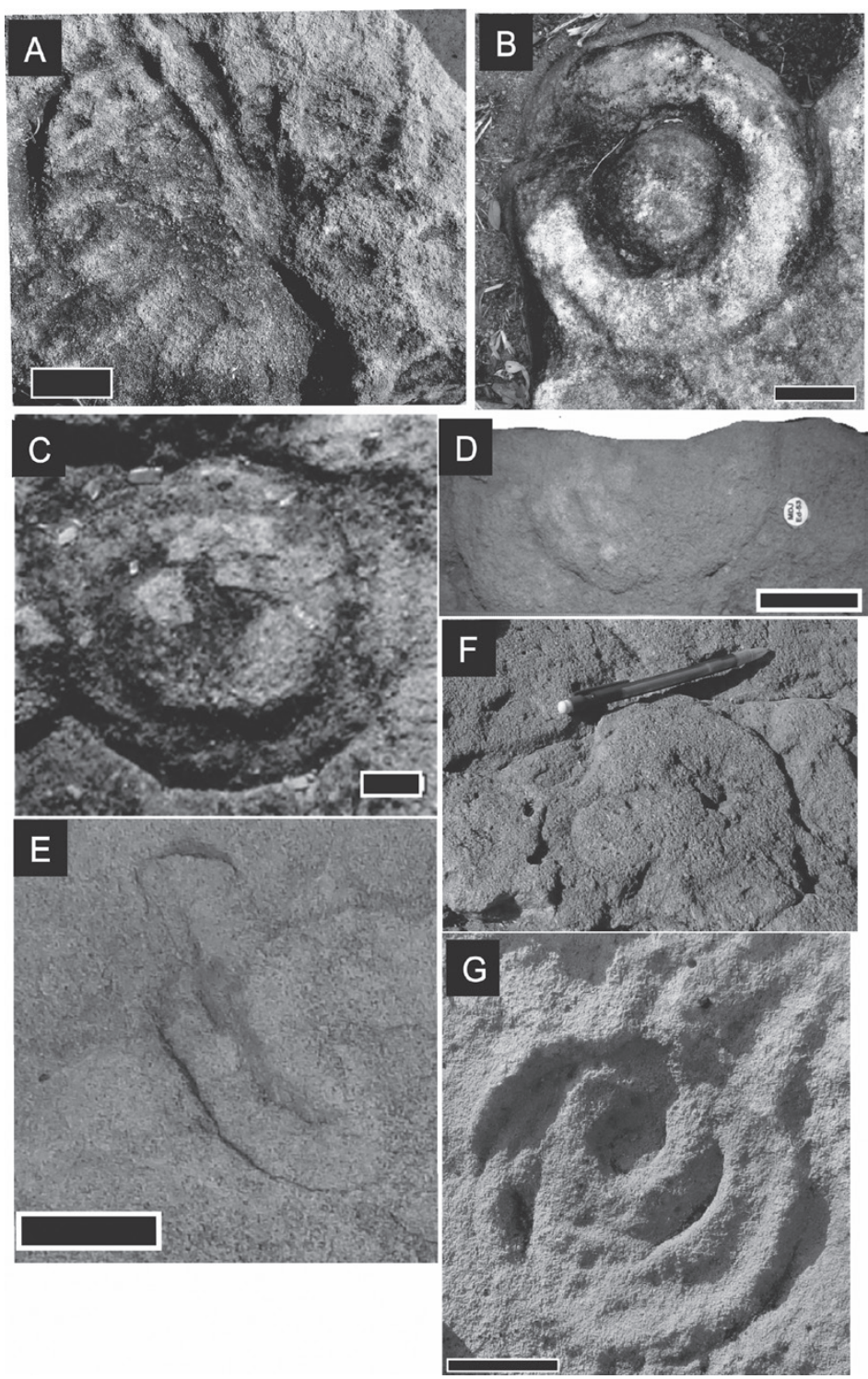

Figure 4 - Ediacaran fauna. A, Charniodiscus arboreus (Scale $3 \mathrm{~cm}$ ); B, Charniodiscus concentricus (Scale $4 \mathrm{~cm}$ ); C, Cyclomedusa davidi (Scale $1 \mathrm{~cm}$ ); D, Ediacaria flindersi (Scale $5 \mathrm{~cm}$ ); E, Kimberella quadrata (Scale $2 \mathrm{~cm}$ ); F, Medusinites asteroides (Scale $15 \mathrm{~cm}$ ); G, Palaeophragmodictya reticulata (Scale $5 \mathrm{~cm}$ ). 
Material: One specimen described and photographed in the field at the Contra Fogo Farm.

Discussion: Gehling and Rigby (1996) described the first occurrence of this species from the Ediacaran Member (Pound Subgroup) in the Flinders Ranges region of southern Australia. Palaeophragmodictya specimens from the Flinders Ranges reached $10 \mathrm{~cm}$ in diameter and exhibited a single central contact point that could be flat or depressed and root-like structures (radial extensions surrounding the edge). Therefore, the Pacujá specimen shares the main taxobases of $P$. reticulata, although it is slightly larger. This species is the only Ediacaran organism whose affinity can be confidently attributed to Porifera.

Genus Parvancorina Glaessner, 1958

Species Parvancorina minchami Glaessner, 1958

(Figure 5A)

Description: A morphologically simple impression consisting of a rounded dorsal shield, widening in the anterior lateral portion and subsequently tapering. A raised ring runs along the edge of the shield. The most prominent feature is a convex anchor shape in the centre of the shield. Anteroposterior region 8.5 $\mathrm{cm}$ in length and $7 \mathrm{~cm}$ in width.

Material: Described and photographed in the field at the Contra Fogo Farm.

Discussion: Previously, this species has been recorded only from the White Sea region in Russia and the Flinders Ranges in Australia. Remnants of these creatures occur only as impressions of the upper side of a rigid shield. Based on the lack of folded parts and deformations surrounding the impression, the Parvancorina sp. body was probably very hard and possibly sclerotic (Ivantsov et al. 2004). The shield shape in P. minchami has been described as a shell, suggesting the inclusion of this species in the class Arthropoda. However, Naimark and Ivantsov (2009) measured hundreds of Parvancorina specimens and found no evidence favouring its affinity with arthropods. They related the size of the specimens to the environmental depth: the greater the depth, the smaller the specimen. The Pacujá specimen is three times larger than the largest specimen recorded by Ivantsov et al. (2004). In Brazil, Parvancorina was found at the Itajaí Basin, in the state of Santa Catarina (Netto 2012).

Genus Pectinifrons Bamforth, Narbonne and Anderson, 2008

Species Pectinifrons abyssalis Bamforth, Narbonne and Anderson, 2008

(Figure 5B)

Description: A comb-like impression with several primary branches diverging from a horizontal axis. Two specimens, both preserved in negative epirelief, with four primary branches. Distance between the first and last primary branch on opposing extremities $12 \mathrm{~cm}$ in the larger specimen, $7 \mathrm{~cm}$ in the smaller specimen. Average width of the primary branches $2 \mathrm{~cm}$ in the larger specimen, $1.5 \mathrm{~cm}$ in the smaller specimen. Average height of the primary branches $3 \mathrm{~cm}$ in both specimens.

Material: Two specimens described and photographed in the field at the Contra Fogo Farm.

Discussion: This species has previously been found only in the Mistaken Point Formation (Conception Group) and the overlying Trepassey Formation (St. John's Group) in Newfoundland (Bamforth et al. 2008). These formations contain the oldest Ediacaran fauna in the world (Laflame and Narbonne 2008b). The measurements of the specimens described above are within the range of measurements for Pectinifrons from Mistaken Point, sharing greater similarity to Morphotype 1 , in which only the inner central branch of each primary support is preserved, without any evidence of frond-like secondary structures. The main axis, which was horizontally disposed in the substrate, 
and the primary supports, representing the central branches of the fronds, were originally composed of resistant materials that did not decompose even after lithification (Bamforth et al. 2008). The Pectinifrons specimens from Mistaken Point are associated with Fractofusus, Charnia, Charniodiscus, Ivesheadia and Aspidella discs.

ICHNOFOSSILIFEROUS ASSOCIATION

Ichnogenus Arenicolites Salter, 1857

(Figure 5C)

Description: Simple, U-shaped excavations without spreite, oriented perpendicularly to the stratification.

Material: Described and photographed in the field at the Contra Fogo Farm.

Discussion: This observation confirms the presence of Arenicolites in the Neoproterozoic. The specimens described here conform to the proposed taxobases for this ichnogenus. In addition, the association of these specimens with Planolites montanus eliminates any possibility of their being sedimentary structures. Notably, Crimes (1992) included Arenicolites and Planolites in his review of ichnofossils appearing in the Neoproterozoic and crossing the Neoproterozoic-Cambrian boundary, corroborating the data presented here. These data refute the claim by Gehling et al. (2001) that Arenicolites have not been convincingly described in Neoproterozoic strata but are often confused with inorganic structures.

Ichnogenus Palaeophycus Hall, 1987

(Figure 5D)

Description: Cylindrical intrastratal excavations oriented horizontally to the stratification, straight to slightly curved, slightly wavy to flexuous, with smooth surfaces.

Material: Described and photographed in the field at the Contra Fogo Farm.
Discussion: Due to its morphological simplicity, Palaeophycus is one of the most common ichnogenera associated with the Ediacaran fauna. However, most species have millimetric diameters. Hagadorn and Waggoner (2000) described Palaeophycus specimens from the Great Basin of the United States as Ediacaran representatives.

Ichnogenus Planolites Nicholson, 1873

(Figure 5E)

Description: Meandering excavations oriented horizontally to obliquely relative to the stratification, sometimes intersecting, rarely branched, circular to elliptical in cross-section, with variable dimensions and configurations.

Material: Described and recorded in the field at the Contra Fogo Farm.

Discussion: Planolites is considered one of the ichnogenera appearing in the Neoproterozoic and remaining in the Phanerozoic (Crimes 1992). Representatives of this ichnogenus have been described from the Neoproterozoic in Uruguay (Aceñolaza et al. 1998) in a volcanic-sedimentary sequence related to the Brasiliano Cycle and from below the Neoproterozoic-Cambrian boundary in Canada (Gehling et al. 2001). In Newfoundland, Arenicolites and Planolites have been recorded only in Cambrian units (Droser et al. 2002). In Brazil, Planolites and Palaeophycus have been described from the Vendian of the Camaquã Basin, in the state of Rio Grande do Sul (Fernandes et al. 2002, Netto 2012).

\section{DISCUSSION}

The Ediacaran faunal impressions of northeastern Brazil and their associated ichnofossils share features of the White Sea Assemblage (Waggoner 2003), whose typical representatives are well known from Australia and Russia. Based on the fossil assemblage, a minimum age of 560 Ma can 


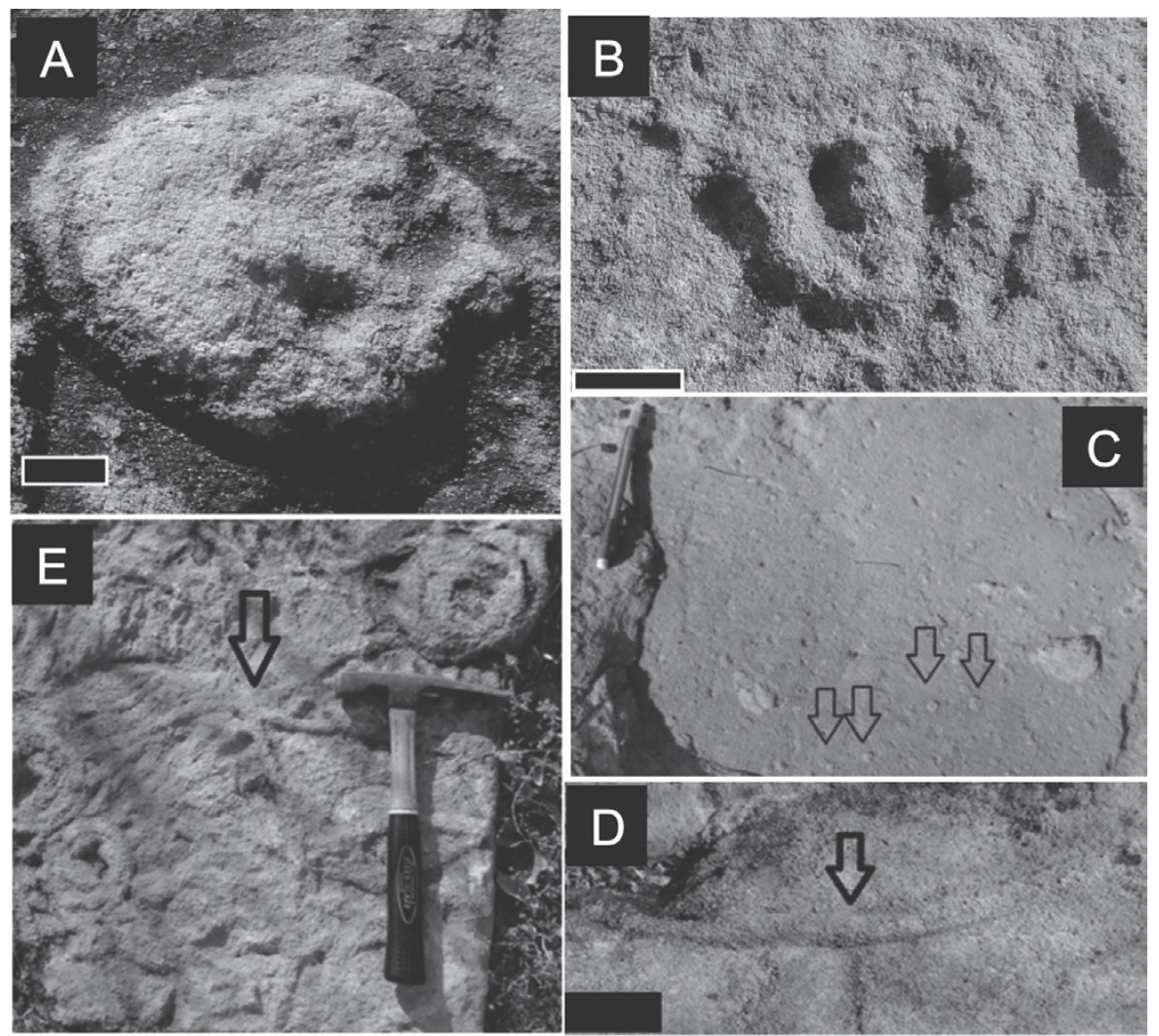

Figure 5 - Ediacaran fauna: A, Parvancorina minchami (Scale $1 \mathrm{~cm}$ ); B, Pectinifrons abyssalis (Scale $3 \mathrm{~cm}$ ); and ichnofossiliferous association: C, Arenicolites Salter, 1857 (Scale $15 \mathrm{~cm}$ ); D, Palaeophycus Hall, 1987 (Scale $3 \mathrm{~cm}$ ); E, Planolites Nicholson, 1873 (Scale $20 \mathrm{~cm}$ ).

be inferred for the deposits studied here. However, Pectinifrons abyssalis is an intruded fossil belonging to the Avalon Assemblage, the oldest in the world.

The age of the Ediacaran fauna contained in the Contra Fogo Sandstone is consistent with previous datings for the key events in the evolution of the Jaibaras Basin (B.B Brito Neves and M.M.C. Neto, unpublished data; F.R.G. Novais et al., unpublished): the Brasiliano Cycle (670-490 Ma), orogeny (625$580 \mathrm{Ma})$, the Mucambo Granite $(548+24 \mathrm{Ma})$, the metamorphism of Pacujá Formation $(535+27 \mathrm{Ma})$ and the Neoproterozoic sedimentation inferred, the Meruoca Granite (540+7 Ma) and the Parapuí Suite (502+8 Ma).

The presence of $P$. abyssalis is better understood as a geographical intrusion, as suggested by analysis of the palaeogeographical map of Veevers (2004). The dominance of taxa described from Russia and Australia can be attributed to the environmental conditions at the time of deposition; both areas were shallower environments.

The action of microbial mats, which is considered primarily responsible for the process of fossilisation without mineralisation, is inferred to have been minimal or absent in the Contra Fogo Sandstone fauna due to the intense bioturbation of the substrate and the sediment particle size. The ichnofossils associated (Paleophycus and Planolites) had been described in Ediacaran deposits worldwide, including Brazil (Netto 2012)

The specimens of the Ediacaran assemblage from northeastern Brazil are much larger than conspecific specimens from elsewhere in the world. For example, the Parvancorina minchami specimen described here is three times larger than the largest specimen recorded by Ivantsov et al. (2004). Similarly, the Pacujá specimen of Medusinites asteroides is $10 \mathrm{~cm}$ in 
diameter, while specimens from Australia are between 1 and $5 \mathrm{~cm}$ in diameter (Glaessner and Wade 1966).

This larger size may have been a deciding factor in the preservation of the organisms as moulds. Bioturbation would have increased the oxygenation of the environment and thus decreased the chances of fossilisation. Smaller individuals may have been present but would have been bioturbed soon after burial.

\section{CONCLUSIONS}

These rocks, which contain Ediacaran fossils, may represent a new geological event between the Pacujá Formation and the Aprazivel Formation of the Jaibaras Basin.

Field analyses suggest a meandering fluvial to estuarine environment for the Contra Fogo Sandstone. The high abundance and diversity of the fossil assemblage, indicate that the depth, salinity, oxygenation and light conditions of this environment were appropriate for faunal development.

The ichnofossiliferous assemblage confirms the presence of Arenicolites, Palaeophycus and Planolites in the Ediacaran.

The predominance of discs representing frond bases rather than full fronds is probably related to high environmental oxygenation and to intense bioturbation, which may have restricted the activity of the microbial mats that would have preserved the more fragile portions.

Pectinifrons abyssalis, previously recorded only in Newfoundland, is also present among the ichnofossils of the Contra Fogo Sandstone.

Based on the predominance of representatives from the White Sea Assemblage, the inferred age of the deposits is at least $560 \mathrm{Ma}$, but the ichnofossiliferous species extend these deposits to Cambrian. This date is consistent with the ages of the key events in the Jaibaras Basin, including the Pacujá Formation.

\section{ACKNOWLEDGMENTS}

We thank the director of the Pacujá Museum, Alancardec Leopoldino for guiding the authors to the outcrops and facilitating access to the sites; the Master's student Robbyson Mendes and Prof. Regina Raick for support during fieldwork; the Conselho Nacional de Desenvolvimento Científico e Tecnológico (CNPq) for the Master's program fellowship granted to author 1 and for the funds provided through project 401781/2010, coordinated by author 2. We also thank the Museum for housing the specimens and for providing free access to the Palaeontology Collection; and LAGESE and LABOPALEO for their support during the preparation of this paper.

\section{RESUMO}

Este estudo relata a primeira ocorrência da fauna Ediacarana no Nordeste do Brasil (Município de Pacujá, noroeste do Estado do Ceará) e apresenta interpretações preliminares de seu significado. A correlação regional indica que os fósseis se originaram na Bacia do Jaibaras e que podem representar um novo sistema geológico. $\mathrm{O}$ ambiente de deposição pode ser atribuído a um sistema transicional. Nove espécies Ediacaranas podem ser identificadas, incluindo membros de grupos pandêmicos (ex. Charniodiscus arboreus Glaessner, 1959; ?Charniodiscus concentricus Ford, 1958; Cyclomedusa davidi Sprigg, 1947; Ediacaria flindersi Sprigg, 1947; e Medusinites asteroides Sprigg, 1949) e grupos endêmicos (ex. Kimberella quadrata Glaessner \& Wade, 1966; Palaeophragmodictya reticulata Gehling \& Rigby, 1996; Parvancorina minchami Glaessner, 1958; e Pectinifrons abyssalis Bamforth, Narbonne, Anderson 2008). Três icnogêneros também estão presentes: Arenicolites Salter, 1857; Palaeophycus Hall, 1987; e Planolites Nicholson, 1873. A idade relativa dos depósitos está entre o ?Ediacarano e Cambriano, e a fauna assemelhase a Assembleia White Sea. A bioturbação apresenta típicos icnogêneros Ediacara não ramificados com pouca profundidade no substrato. Esta ocorrência até então desconhecida da fauna de Ediacarano reforça a importância do Estado do Ceará para a paleontologia brasileira e global.

Palavras-chave: Brasil, estado do Ceará, fauna de Ediacara, ambiente transicional, Assembleia White Sea. 


\section{REFERENCES}

Aceñolaza FG, Bettucci LS AND Fernicolo JC. 1998. Icnofósiles del Grupo Lavalleja, Neoproterozoico de Uruguay. Col Paleontol 49: 9-21.

Almeida FFM, Melcher GC, Cordani UG, KaWAshita K AND VANDOROS P. 1968. Radiometric age determinations from northern Brazil. Soc Bras Geol Bol 17: 3-14.

BABCOCK EL, GRUNNOW AM, SADOWSKI GR AND LESLIE SA. 2005. Corumbella, an Ediacaran-grade organism from the Late Neoproterozoic of Brasil. Palaeogeogr Palaeoclimatol Palaeoecol 220: 7-18.

BAMFORTH EL, NARBONNE GM AND ANDERSON MM. 2008. Growth and ecology of multi-branched Ediacaran Rangeomorph from Mistaken Point assemblage, Neufoundland. J Paleontol 82: 763-777.

Bertrand-SArfati J, Moussine-Pouchkine A, Armad B AND AHMED AAK. 1995. First Ediacaran Fauna found in western Africa an evidence for an Early Cambrian glaciations. Geology 23: 133-136.

Brito Neves BB, VAn Schmus WR And Fetter AH. 2001. Noroeste da África - Nordeste do Brasil (Província Borborema) Ensaio comparativo e problemas de correlação. Rev Inst Geol 1: 59-78. [online]

CAVAlCANTE JC, VASCONCELOS AM AND GOMES FEM. 2003. Atlas de geologia e recursos minerais do Ceará. Sistema de informações Geográficas SIG, Secretaria dos Recursos Hídricos do Estado do Ceará. CPRM/Serviço Geológico do Brasil, Fortaleza, CD-Rom.

Costa MJ, França JB, Bacciegga IF, Habekost CR AND CruZ WB. 1973. Geologia da Bacia do Jaibaras; Ceará, Piauí e Maranhão. Projeto Jaibaras. DNPM/CPRM. Recife.

CRIMES TP. 1992. Changes in the trace fossil biota across the Proterozoic-Phanerozoic boundary. J Geol Soc London 149: 631-646.

CRIMES TP AND MCILROY D. 1999. A biota of Ediacaran aspect from lower Cambrian strata on the Digermul Peninsula, Arctic Norway. Geol Mag 6: 633-642.

De Araújo CEG, Cordani UG, Basei mas, CAstro AN, SATO K AND SPROESSER WM. 2012. U-Pb detrital zircon provenance of metasedimentary rocks from the Ceará Central and Médio Coreaú Domains, Borborema Province, NEBrazil: Tectonic implications for a long-lived Neoproterozoic active continental margin. Precambrian Res 206-207: 36-51.

DE C. 2006. Ediacaran fossil assemblage in the upper Vindhyans of Central India and its significance. J Asian Earth Sci 27: 660-683.

Delgado IM ET AL. 2003. Geotectônica do Escudo Atlântico. In: BIZZI LA, SCHOBENHAUS C, VIDOTTI RM AND GONÇALVES JH (Eds), Geologia, Tectônica e Recursos Minerais do Brasil, Brasília: CPRM. Serviço Geológico do Brasil, p. 227-334.

DREFAHLMANDSILVARC.2007. Ocorrências de fósseis Ediacaranos na Formação Camarinha (Neoproterozóico Superior), sudeste do Estado do Paraná. In: CARVALHO IS (Eds), Paleontologia: Cenários de Vida, Rio de Janeiro: Interciência, p. 3-11.
Droser ML, Jensen S And Gehling J. 2002. Traces fossils and substrates of the terminal Proterozoic-Cambrian transition: Implications for the record of early bilaterians and sediment mixing. PNAS 99: 12572-12576.

FAIRCHILD TR AND BoGGIANI PC. 2010. A vida primitiva: do Criptozoico (Pré-Cambriano) ao início do Fanerozóico. In: CARVALHO IS (Eds), Paleontologia: conceitos e métodos, Rio de Janeiro: Interciência, p. 325-337.

FEDOnKIn MA AND WagGOner BM. 1997. The Late Precambrian fossil Kimberella is a mollusc-like bilaterian organism. Nature 388: 868-871.

Fernandes ACS, Borghi L, CARVAlHo IS AND ABReU CJ. 2002. Guia dos Icnofósseis de Invertebrados do Brasil, Rio de Janeiro: Interciência, 260 p.

FORD TD. 1999. The Precambriam fossils of Charnwood Forest. Geol Today, p. 230-234.

Gehling JG, Jensen S, Droser ML, Myrow PM AND NARBONNE GM. 2001. Burrowing below the basal Cambrian GSSP, Fortune Head, Newfoundland. Geol Mag 138: 213-218.

GEHLING JG AND RigBY JK. 1996. Long expected sponges from the Neoproterozoic Ediacara Fauna of South Australia. J Paleontol 70: 185-195.

GLAESSNER MF AND WAdE M. 1966. The late Precambrian fossils from Ediacara, South Australia. Paleontology 9: 599-628.

Hagadorn JW And WagGoner B. 2000. Ediacaran fossils from the Southwestern Great Basin, United States. J Paleontol 74: 349-359

IVANTSOV AY. 2009. New reconstruction of Kimberella, problematic Vendian metazoan. Paleontol J 43: 601-611.

IVANTSOV AY, MALAKHOVSHAYA YE AND SEREZHIKOVA EA. 2004. Some problematic fossils from the Vendian of the Southeastern White Sea Region. Paleontol J 38: 1-9.

Kegel W, Scorza EP AND Coelho FCP. 1958. Estudos geológicos do Norte do Ceará. Bol Div Geol Min 184: 1-46.

LAFLAME M AND NARBONNE GM. 2008A. Ediacaran fronds. Palaeogeogr Palaeoclimatol Palaeoecol 258: 162-179.

LAFlame M And Narbonne GM. 2008B. Competition in a Precambrian world: palaeocology of Ediacaran fronds. Geol Today 24: 182-187.

Mabessone JM. 2002. História Geológica da Província Borborema (NE Brasil). Rev Geol UFC 15: 119-129.

MCCALL GJH. 2006. The Vendian (Ediacaran) in the geological record Enigmas in geology's prelude to the Cambrian explosion. Earth-Sci. Rev 77: 1-229.

NAIMARK EB AND IVANTSOV AY. 2009. Growth variability in the Late Vendian Problematics Parvancorina Glaessner. Paleontol J 43:12-18.

NARBONNE GM. 2005. The ediacara biota: neoproterozoic origin of animals and their ecosystems. Annu Rev Earth P1 Sc 33: 421-442.

NETTO RG. 2012. Evidences of life in terminal proterozoic deposits of southern: a synthesis. In: NETTO RG, CARMONA NB AND TOGNOLI FMW (Eds), Ichnology of Latin America - selected papers. Porto Alegre: SBP, Monografias da Sociedade Brasileira de Paleontologia, p. 15-26. (Unpublished). 
OLIVEIRA DC. 2000. Stratigraphic interplays between igneous and sedimentary events in the early palaeozoic Jaibaras Trough (Northeast Brazil). RBG 30: 427-431.

OLIVEIRA DC. 2001. Reavaliação da evolução tectonomagmática do Graben de Jaibaras (Nordeste do Brasil). Act Geol Hisp 36: 53-95.

OLIVEIRA DC AND MOHRIAK WU. 2003. Jaibaras Trough: an important element in the early tectonic evolution of the Parnaiba sag basin, northeastern Brazil. Mar Petrol Geol 20: 351-383.

Peterson KJ, Waggoner B and Hagadorn JW. 2003. A fungal analog for Newfoundland Ediacaran fossils? Integr Comp Biol 43: 127-136.

SANTos EJ AND BRITo Neves BB. 1984. Província Borborema. In: ALMEIDAFFMAND HASUIY (Eds), O Pré-cambriano do Brasil, São Paulo: Edgard Bluncher, p. 123-186.

SCHOBBENHAUS CAND BRITO NEVES BB. 2003. Geologia do Brasil no contexto da Plataforma Sul Americana. In: BIZZI AL, SCHOBBENHAUS C, VIDOTTI MR AND GONÇALVES JH (Eds), Geologia, tectônica e recursos minerais do Brasil, Brasília: Serviço Geológico do Brasil-CPRM, p. 5-54.

SEILACHER A. 1992. Vendobionta and Psammocolaria: lost constructions of Precambrian evolution. J Geol Soc London 149: 607-613.
SiAL AN, FigueIREDO MCH AND LONG LE. 1981. Rare-earth element geochemistry of Meruoca and Mucambo Plutons, Ceará, Northeast Brazil. Chem Geol 31: 271-283.

TAVARES JR SS, GORAYEB PSS AND LAGON J-M. 1990 Petrografia e geocronologia $\mathrm{Rb} / \mathrm{Sr}$ do feixe de diques da borda oeste do Granito de Meruoca (CE). Anais do $36^{\circ}$ Congresso Brasileiro de Geologia, Natal, p. 337-338.

TORQUATO JR. 1995. A geologia do Noroeste do Ceará (uma visão histórica). Rev Geol UFC 8: 5-183.

TORQUATO JR AND NogUeIRA Neto JA. 1996. Historiografia da região de dobramentos do Médio Coreaú. RBG 26: 303-314.

VANDOROS P AND OLIVEIRA MAF. 1968. O fonótipo MecejanaCE. An Acad Bras Cienc 40: 203-206.

VAZ PT, Rezende NGA, Filho JRW and TraVassos WAS 2007. Bacia do Parnaíba. Bol Geoc Petrobras 15: 253-263.

VEEVERS JJ. 2004. Gondwanaland from 650-500Ma assembly through 320 Ma mergers in Pangea to 185-100 Ma breakup: supercontinental tectonics via stratigraphy and radiometric dating. Earth Sci Rev 68: 1-132.

WAGGONER B. 1998. Interpreting The Ealiest Metazoan Fossils: What Can We Learn? Am Zool 38: 975-982.

WAGGONER B. 2003. The Ediacaran Biotas in space and time. Integr Comp Biol 43: 104-113. 